\title{
Association between Polymorphisms of SNPs Located at the 3'-Untranslated Region of SET8 and Codon 72 of the TP53 with Breast Cancer among Cameroonian Women
}

\author{
Arnol Auvaker Zébazé Tiofack ${ }^{1}$, Elvis A. Ofon'1, Esther Dina Bell2 ${ }^{2}$ Chancelin M. Kamla ${ }^{3}$, \\ Roger Tchamfong ${ }^{4}$, Smiths Lueong1,5, Gustave Simo ${ }^{*}$ \\ ${ }^{1}$ Molecular Parasitology \& Entomology Unit, Department of Biochemistry, Faculty of Science, University of Dschang, \\ Dschang, Cameroun \\ ${ }^{2}$ Medical Oncology, Direction of the Bonassama District Hospital, Douala, Cameroon \\ ${ }^{3}$ Faculty of Medicine and Pharmaceutical Science, University of Douala, Douala, Cameroon \\ ${ }^{4}$ St. Joseph Clinic Cancer Center, Yaounde, Cameroon \\ ${ }^{5}$ German Cancer Research Center, Essen, Germany \\ Email: auvaker@yahoo.fr, jeaofoninhao@yahoo.com, esther.dinabell@gmail.com, chancelinkamla@yahoo.fr, \\ tchamfongroger@yahoo.fr, s.lueong@Dkfz-Heidelberg.de, * gsimoca@yahoo.fr, ${ }^{\star}$ gustave.simo@univ-dschang.org
}

How to cite this paper: Tiofack, A.A.Z., Ofon, E.A., Bell, E.D., Kamla, C.M., Tchamfong, R., Lueong, S. and Simo, G. (2020) Association between Polymorphisms of SNPs Located at the 3'-Untranslated Region of SET8 and Codon 72 of the TP53 with Breast Cancer among Cameroonian Women. Journal of Biosciences and Medicines, 8, 23-45. https://doi.org/10.4236/jbm.2020.811004

Received: September 19, 2020 Accepted: November 6, 2020 Published: November 9, 2020

Copyright $\odot 2020$ by author(s) and Scientific Research Publishing Inc. This work is licensed under the Creative Commons Attribution International License (CC BY 4.0).

http://creativecommons.org/licenses/by/4.0/ (c) (i) Open Access

\begin{abstract}
In sub-Saharan Africa, breast cancer (BC) constitutes a serious public health problem and the genetic basis of its development is remaining poorly understood. Although the SNPs at codon 72 of TP53 (rs1042522) and at the UTR of SET8 (rs16917496) have both been associated with BC development among Asian and European women, no published data has been reported within African population. We herein report on the impact of these polymorphisms on the risk of $\mathrm{BC}$ among Cameroonian women. Blood samples were collected from 111 breast cancer patients and 224 controls. DNA was extracted from each sample and PCR-RFLP was used to investigate the polymorphisms at SNPs rs1042522 of TP53 and rs16917496 of SET8. Association studies were performed according to ethno-linguistic groups and menopausal status. The minor allele "T" of $S E T 8$ gene revealed a protective effect in premenopausal women (OR, $0.327 ; 95 \%$ CI 0.125 - 0.852) while the CT genotype of SET8 was associated with increased risk of BC (OR, 2.93; 95\% CI, $1.1-7.8$ ). The minor "G" allele of TP53 gene was significantly associated (OR, 2.533; 95\% CI, 1.455 - 4.408) with increased disease risk in premenopausal women while the CG genotype was significantly associated (OR, 0.39; 95\% CI, 0.23 $0.69)$ with decreased risk of BC. A synergistic genetic interaction at both loci for CC genotype of SET8 and CG genotype of TP53 was associated (OR, 0.46;
\end{abstract}


95\% CI, 0.24 - 0.91) with reduced disease risk. No significant association between polymorphisms at the SET8 and TP53 loci and clinical pathologic features of BC was observed. This study suggests significant associations between the SNPs located at the 3'-UTR of SET8 and codon 72 of the TP53 with the risk of breast cancer development among premenopausal women. There is an interaction between TP53 and SET8 genes.

\section{Keywords}

SNPs, TP53, SET8, Breast Cancer, Women, Cameroon

\section{Introduction}

Breast cancer (BC) is the most predominant cancer in women worldwide with about 2.2 million new cases diagnosed in 2018 [1]. Although the incidence of BC is relatively low in developing countries, the mortality rates are very high. According to the International Agency for Cancer Research (IARC), BC incidence ranges from 28 per 100,000 women in central Africa to more than 37 per 100,000 women in Western Africa [1]. More than 50\% of BC-related deaths occur in low-income countries probably due to advanced-stage at diagnosis and disease aggressiveness [2] [3] [4] [5]. Although enormous efforts have been undertaken to better understand BC etiology, several aspects remain underexplored, especially in sub-Saharan Africa where the disease is characterized by different epidemiological features. Although about 53,917 new breast cancer cases have been reported in North Africa, more than 114,707 new cases have been recorded in sub-Saharan Africa [1]. Moreover, amongst young women of 15 to 49 years, the incidence of breast cancer in North Africa is lower than in sub-Saharan African countries [1]. Women of Sub-Saharan African region also have a higher risk for early-onset, high-grade, node-positive and hormone receptor-negative disease [6]. Although lifestyle factors have been proposed to partially explain these observed features [7] [8] [9], studies addressing BC genetics have highlighted the role of genetic factors. In the light of the foregoing, polymorphism at some specific genetic markers such as single-nucleotide polymorphisms (SNPs) have been postulated to explain the differences in $\mathrm{BC}$ outcome based on the race and/or ethnicity [10] [11] [12].

Single-nucleotide polymorphisms are the most frequent type of variation in the human genome [13]. Several studies have shown SNPs as important genetic variants that could help to predict individual susceptibility to various cancers and response to certain drugs [14] [15]. In some epidemiological investigations, SNPs in critical genes have been examined in order to unravel associations between specific alleles and genotypes with the risk of cancer development and/or the appearance of a specific pattern of cancer development [16] [17]. Recent investigations on the genetic bases of breast cancer revealed that one SNP of the TP63 gene was associated with reduce risk of breast cancer development in Ca- 
meroonian women [18]. However, other SNPs that have shown some associations with cancer development remain to be investigated in sub-Saharan African countries. For instance, the SNP (rs1042522) in codon 72 of TP53 has shown no associated with breast cancer in Rwandese Population [19]. However, for the same SNP, other studies reported its association with the risk of developing several cancers including breast cancer [20]; thus highlighting its potential role in the development of breast cancer in other populations. This SNP produces two variants $\mathrm{G}$ and $\mathrm{C}$ with distinct biological and biochemical properties [21]. It has been reported to play important role by mediating apoptotic response [22]. It has been also associated with the risk of developing cancer including BC. Moreover, polymorphism at SNP rs16917496 T/C located at the 3'UTR of SET8 has been associated with BC risk in young Asian women [23]. Subsequent investigations have shown this SNP to be a susceptibility factor for a number of cancers including non-small cell lung cancer [24], childhood acute lymphoblastic leukemia and cervical cancer [25]. Remarkably, TP53 and SET8 genes may have some biological molecular interactions. For instance, as a methyltransferase, SET8 methylates TP53 gene at Lys-382, which may affect the gene function [26]. By this methylation, there is an interaction between the SET8 and TP53 gene products and polymorphism on these genes could alter their function. The deletion at the SET8 gene increased proapoptotic and checkpoint activation functions of TP53 [27]. Thus, polymorphism in either the $S E T 8$ or $T P 53$ genes may lead to the loss of homeostatic control during human carcinogenesis [28] [29]. However, there is no evidence to show a correlation between the SNP in the 3'-UTR of SET8 (rs16917496 C/T) and BC in Sub-Saharan Africa population. Meanwhile the aforementioned SNPs have been associated with the risk of $\mathrm{BC}$ in young Asian women [23], no published data has shown their implications in the risk of developing BC in African women. Understanding the impact of these SNPs in the development of BC in sub-Saharan Africa may help in designing well-tailored preventive measures and sensitization measures.

We herein report on the association between polymorphisms at two SNPs of SET8 and TP53 genes with risk of BC in Cameroonian women both as independent factors as well as in an interaction model.

\section{Materials and Methods}

\subsection{Ethical Approval and Consent to Participate}

This study was approved by the Ethics Review and Consultancy Committee (ERCC) of the Cameroon Bioethics Initiative (CAMBIN) under the reference number CBI/ 395/ERCC/CAMBIN and Protocol number 1086, according to standards of the Declaration of Helsinki. All study participants received explicit information about the study and voluntarily consented by signing an informed consent form.

\subsection{Study Population}

The Cameroonian population is made up of more than 250 ethno-linguistic sub- 
groups from three major ethnic groups: Bantu (e.g.: Bulu, Bassa, Bakundu, Maka, Douala), Semi Bantu (e.g.: Bamileke, Gbaya, Bamoun, Tikar) and SudanoSao (e.g.: Fulbe, Mafa, Toupouri, Shoa-Arabs, Moundang, Massa, Mousgoum) [30]. Beside these three groups, some minor groups exist such as the Baka who generally speak the Bantu languages but who are not closely related to any of these three major groups [31]. For this study, a total of 335 women including 111 breast cancer patients and 224 controls were recruited between October 2015 and December 2016. They belong to Bantu, Semi-Bantu and Sudano-Sao ethno-linguistic groups. All BC patients were histologically confirmed of having invasive BC, but without other clinically detectable neoplasm. These patients were treated at the oncology and radiotherapy unit of the Douala General Hospital and the St. Joseph clinic cancer center of Yaoundé. Patients were included only if they were Cameroonians, consented to participate to the study and did not have other known neoplasms. From each patient, clinical and pathological data including age at the diagnosis, tumor localization, histological sub-type and clinical stage of the disease were obtained from the physician and/or collected from hospital records. Controls were void of any form of neoplasm as determined from their medical histories and general physical examination. Controls were randomly recruited amongst women attending the same hospitals as the patients. All women who accepted to participate to the study signed a consent form and filled out a structured questionnaire.

\subsection{Blood Sampling and DNA Extraction}

About $5 \mathrm{ml}$ of whole blood sample was taken by vein-puncture into EDTA-coated tubes. After centrifugation at $3000 \times \mathrm{g}$ for 5 minutes, the buffy coat was collected. From each buffy coat, DNA was extracted using phenol-chloroform-isoamylic alcohol (25:24:1) as described by Kerney [32] and then, precipitated with isopropanol. The DNA pellets were washed twice with $70 \%$ cool ethanol and then dried at room temperature. DNA pellets were finally re-suspended in $50 \mu \mathrm{l}$ of sterile ultrapure water and stored at $-20^{\circ} \mathrm{C}$ until use.

\subsection{Genotyping of SNPs in SET8 and TP53 Genes}

In this study, the SNPs in SET8 and TP53 were investigated by PCR-RFLP where a DNA fragment of each of these genes was amplified and subsequently digested by a specific restriction enzyme. The following primer pairs were used: SET8-Fow (5'-TGAGCTGAGGTGTGAGCCTA-3') and SET8-Rev (5'-AGAGTTCTGGGA AACACGCT-3') for SET8, sense 5'-ATGGGACTGACTTTCTGCTCTTG-3' and anti-sense 5'-GGAAGCCAAAGGGTGAAGAGG-3' for TP53. These primers were designed using Primer-BLAST software as described by Ye et al. [33]. For each of these genes, the PCR reactions were performed in total volume of $25 \mu \mathrm{L}$ containing $1 \times$ PCR buffer (Tris. Cl, $\left.\mathrm{KCl},\left(\mathrm{NH}_{4}\right)_{2} \mathrm{SO}_{4}, 0.15 \mathrm{mM} \mathrm{MgCl}_{2}\right), 1 \times$ Q-Solution (Cat No./ID: 203203 Qiagen, Germany), $1.25 \mu \mathrm{L}$ of each primers (20 picoM), 0.5 $\mu \mathrm{L}(10 \mathrm{mM} / \mathrm{L})$ of each dNTP, $0.3 \mathrm{mM}$ of additional $\mathrm{MgCl}_{2}(25 \mathrm{mM}), 0.125 \mu \mathrm{L}$ of 
Hot star Taq DNA polymerase (5 U/ $\mu$ l; Cat No./ID: 203203, Qiagen, Germany) and $5 \mu \mathrm{L}$ of 10 -fold diluted genomic DNA extract and supplemented with sterile ultrapure water. The amplification program was made up of an initial denaturation step of $95^{\circ} \mathrm{C}$ for $15 \mathrm{~min}$ followed by 40 cycles of $95^{\circ} \mathrm{C}$ for $45 \mathrm{~s}, 58^{\circ} \mathrm{C}$ and $57^{\circ} \mathrm{C}$ for $45 \mathrm{~s}$ respectively for $S E T 8$ and $T P 53$, and $72^{\circ} \mathrm{C}$ for $1 \mathrm{~min}$, and a final extension step of $72^{\circ} \mathrm{C}$ for $10 \mathrm{~min}$.

PCR products from different amplification reactions were resolved by electrophoresis on $2 \%$ agarose gel, visualized under UV-light and documented with UVItec (Cambridge, UK). All successfully amplified samples (a DNA fragment of $700 \mathrm{bp}$ for $S E T 8$ or $500 \mathrm{bp}$ for TP53) were selected and subsequently subjected to restriction digestion.

For this digestion, ten micro-liters of SET8 or TP53 PCR products were digested with SwaI and BstUI respectively (cat \# New England BioLabs, Inc. country). The digestion was performed overnight at $25^{\circ} \mathrm{C}$ and $60^{\circ} \mathrm{C}$ respectively in the buffers NEBuffer 3.1 for SwaI and NEBuffer CutSmart for BstUI. The digested products were resolved on 2\% agarose gel (FMC Bio Products) at 100 volts for 90 minutes and documented using a UVItec (Cambridge, UK) gel documentation system. The expected size of DNA fragments resulting from the digestion of PCR products was determined using the online Restriction Map software (Restriction Mapper version 3) at http://www.restrictionmapper.org. This was done by simulating the digestion of each PCR product sequence with the corresponding restriction enzyme identified in the previous studies (Table 1). For $S E T 8$ and TP53 loci, three different profiles were expected (Table 1): 1) the homozygote wild type genotype with one DNA fragment of $700 \mathrm{bp}$ for SET8 and two DNA fragments of 286 and $214 \mathrm{bp}$ for TP53; 2) the homozygote genotype with two DNA fragments of 203 and $497 \mathrm{pb}$ for SET8 and one DNA fragment of $500 \mathrm{bp}$ for $T P 53 ; 3$ ) and the heterozygote genotype showing three DNA fragments of 203, 497 and 700 bp for SET8, and 214, 286 and 500 bp for TP53 (Table 1).

Amplicons from controls and $\mathrm{BC}$ patients were quantified before their digestion. Equal amount of amplicons was digested to minimize misinterpretation of heterozygote frequency resulting probably from partial digestion. For each series of amplification and digestion, samples with known genotypes were added as internal controls in order to control the reproducibility and digestion efficiency.

Table 1. The expected sizes of PCR products of TP53 and SET8 genes and their fragments digested in relationship with each genotype.

\begin{tabular}{|c|c|c|c|c|c|c|c|}
\hline \multirow{3}{*}{ Gene } & \multirow{3}{*}{ Locus } & \multirow{3}{*}{$\begin{array}{c}\text { Size of } \\
\text { amplicons }\end{array}$} & \multirow{3}{*}{$\begin{array}{l}\text { Restriction } \\
\text { enzyme }\end{array}$} & \multicolumn{3}{|c|}{$\begin{array}{l}\text { Size of digested DNA } \\
\text { fragments in base pair }\end{array}$} & \multirow{3}{*}{ References } \\
\hline & & & & \multirow{2}{*}{$\begin{array}{c}\text { Heterozygote } \\
\text { genotype }\end{array}$} & \multicolumn{2}{|c|}{$\begin{array}{c}\text { Homozygote } \\
\text { genotypes }\end{array}$} & \\
\hline & & & & & Wild type & Mutant & \\
\hline SET8 & rs16917496 T/C & $700 \mathrm{bp}$ & SwaI & $203 / 497 / 700$ & 700 & $203 / 497$ & [23] [24] \\
\hline$T P 53$ & rs1042522 C/G & $500 \mathrm{bp}$ & BstUI & $214 / 286 / 500$ & $286 / 214$ & $500 \mathrm{pb}$ & {$[24][68]$} \\
\hline
\end{tabular}




\subsection{Power Calculation}

The power of this study was calculated using the PGA modeller package in MATLAB [34]. It was estimated by considering an odd ratio (OR) or a relative risk $(\mathrm{RR}) \geq 2$ for the locus with the allele frequency of the disease of 0.085 0.1791 for the two genotyped loci. In addition, the disease prevalence estimated at $0.1 \%$ in women aged from 20 to 74 years according to WHO [35], a type $1 \mathrm{er}-$ ror of $5 \%$ of risk, a complete linkage parameter (r2) of 0.8 for the linkage disequilibrium (LD) [36], a case-control ratio of 1:2 and the size of sampling was also taken into account in the power calculation.

\subsection{Association Analyses}

Before association studies, the HWE test was undertaken on the entire population and different subpopulations stratified according to ethno-linguistic subgroups or menopausal status. Each population or subpopulation was considered in HWE when the $\mathrm{p}$ value (comparing the observed heterozygote rate and that of expected heterozygote) was $\geq 0.05$ using PLINKv1.9 package. Association studies between the polymorphisms at SET8 and TP53 gene loci and the risk of BC development were investigated with a logistic regression model that was performed to estimate odds ratio (OR) at $95 \%$ confidence intervals (CI) in PLINKv1.9 package [37]. They were performed on the entire population as well as different subpopulations represented by ethno-linguistic groups and women with different menopausal status. To avoid standard error resulting from the absence of genotypes or alleles (represented by zero), a value of 0.5 was added to all cells as described previously [38] [39]. Pearson chi-square $\left(\chi^{2}\right)$ tests and Fisher's exact test were used to compare categorical variables between participants while the student $\mathrm{t}$-test was used to compare the mean values for continuous variables between subpopulations using SPSS Software 22.0 (SPSS Inc., Chicago, Illinois, USA). The test was considered significant for a P value below 0.05 .

The Cochran-Mantel-Haenszel (CMH) test implemented in PLINKv1.9 package was performed with the allelic frequencies because this test can only be done with binary variables [37]. Used as an extension of the chi-square test, the CMH allows for the estimation of odds ratio and 95\% confidence interval across the stratified populations represented here by different ethno-linguistic groups and menopausal women. This test enabled to assess the association between alleles and the probability to develop breast cancer within each stratified subpopulation. The CMH2 test, also implemented in PLINKv1.9 package, was used to determine if significant differences exist between the allelic frequencies in different subpopulations. In addition to genotypic and allelic tests, the Cochran-Armitage trend test for interaction between genotypes was performed on the entire and different subpopulations in order to see if there is any association between polymorphism at a given locus and the risk of breast cancer development [40].

To confirm results of association studies generated by $\mathrm{CMH}$ tests, the logistic regression model was performed on different subpopulations stratified by eth- 
no-linguistic subgroup and menopausal status. The Fisher exact test was performed on samples from premenopausal women that were in HWE and that showed significant association with polymorphisms at TP53 and SET8 loci in order to see if there is any association between the genotypic frequencies and different clinico-pathological presentations of BC. It was also performed to assess the implication of the combined polymorphism at TP53 and SET8 loci with risk of BC development [27].

\section{Results}

\subsection{Socio-Demographic and Clinical Characteristics of the Study Population}

For this study, 335 participants were recruited: 111 (33.1\%) BC patients with histologically confirmed infiltrating ductal carcinomas and 224 (66.9\%) controls (Table 2). Amongst these, 74 (22.09\%) were Bantu, 254 (75.82\%) semi Bantu and 7 (2.09\%) Sudano-Sao. The age of BC patients at diagnosis ranged from 24 to 72 years with a mean of $41.64(\mathrm{SD}=12.31)$ years while those of the controls varied from 25 to 78 years with a mean of $39.55(S D=10.63)$ years. No significant difference was observed between mean age of patients and controls $(\mathrm{p}=$ $0.11)$. However, significant differences $(p<0.001)$ were observed between $B C$ patients and controls considering the ethno-linguistic origin, the menopausal status $(\mathrm{p}<0.001)$ as well as familial BC history $(\mathrm{p}<0.001)$ (Table 2$)$.

From all BC patients, 77 (69.37\%) were premenopausal and 34 (30.64\%) postmenopausal. Fifty eight (52.3\%) BC patients were above 40 years while 53 (47.75\%) were aged 40 and below. One hundred and two (91.89\%) patients were either at stage III or IV while $9(8.11 \%)$ were either at stage I or II. Forty one $(36.94 \%)$ patients had a metastatic disease (Table 2) while 71 (63.96\%) had lymph node involvement (Table 2).

Of the 224 controls, 195 (87\%) were premenopausal women while 29 (13\%) were postmenopausal. Moreover, $41.96 \%$ (94/224) of them were above 40 years while $58.04 \%$ (130/224) had 40 years or less (Table 2).

With a complete linkage parameter $(\mathrm{r} 2)$ of 0.8 , a disease prevalence $0.1 \%$ in women aged 20 to 74 , the disease allelic frequencies ranging from 0.085 to 0.1791 for two loci genotyped and a sampling size of 335 individuals including 111 BC patients and 224 controls, the power of this study was estimated at $86 \%$.

\subsection{Amplification of SET 8 and TP53 Genes}

The DNA extracts from 335 participants were successfully amplified for both SET8 and TP53 genes. Figure 1(a) and Figure 1(b) illustrate the electrophoretic profiles obtained on agarose gel. They show the amplicons resulting from the amplification of different DNA extracts. The quality and intensity of bands observed on agarose gel testify not only the good amplification, but also the quality of DNA extracts resulting from phenol-chloroform-isoamyl alcohol extraction method used. 
Table 2. Socio-demographic and clinical characteristics of the study population.

\begin{tabular}{|c|c|c|c|}
\hline Clinical & $\begin{array}{c}\text { Cases, } \\
\mathrm{n}=111(\%)\end{array}$ & $\begin{array}{c}\text { Controls, } \\
\mathrm{n}=224(\%)\end{array}$ & $p$-value \\
\hline Age group & & & 0.11 \\
\hline$>40$ & $58(52.3)$ & $94(41.96)$ & \\
\hline$\leq 40$ & $53(47.75)$ & $130(58.04)$ & \\
\hline Age (means $\pm \mathrm{SD}$ ) & $41.64 \pm 12.31$ & $39.55 \pm 10.63$ & \\
\hline Ethnic group & & & $<0.001$ \\
\hline Bantu & $33(29.73)$ & $41(18.30)$ & \\
\hline Semi Bantu & $72(64.86)$ & $182(81.25)$ & \\
\hline Sudano-sao & $6(5.41)$ & $1(0.45)$ & \\
\hline Menopause status & & & $<0.001$ \\
\hline postmenopausal & $34(30.63)$ & $29(12.95)$ & \\
\hline Premenopausal & $77(69.37)$ & $195(87.05)$ & \\
\hline Familial breast cancer & & & $<0.001$ \\
\hline Yes & $29(26.13)$ & $16(7.14)$ & \\
\hline No & $82(73.87)$ & $208(92.86)$ & \\
\hline \multicolumn{4}{|l|}{ Histological grade } \\
\hline I, II & $9(8.11)$ & - & \\
\hline III, IV & $102(91.89)$ & - & \\
\hline$p$-value & $<0.0001$ & & \\
\hline \multicolumn{4}{|l|}{ Lymph node } \\
\hline Yes & $71(63.96)$ & - & \\
\hline No & $40(36.04)$ & - & \\
\hline$p$-value & $<0.0001$ & & \\
\hline \multicolumn{4}{|l|}{ Metastasis } \\
\hline Yes & $41(36.94)$ & - & \\
\hline No & $70(63.06)$ & - & \\
\hline$p$-value & $<0.0001$ & & \\
\hline
\end{tabular}

\subsection{Genotyping of Different SNPs}

According to SNPs that were investigated, different electrophoretic profiles were generated after digestion of PCR products. Figure 2 is an example of electrophoretic profiles illustrating DNA fragments resulting from the digested PCR products of $S E T 8$ and TP53 genes. All study participants were successfully genotyped at SET8 and the TP53 gene loci. At the SET8 locus, 97 (87.39\%) cases were homozygote wild-type with CC genotype while 14 (12.61\%) were heterozygote with CT genotype. In the control group, 183 (81.70\%) were homozygote wild-type (CC), 39 (17.41\%) heterozygote (CT) and 2 (0.89\%), homozygote mutant (TT) (Table 3). 


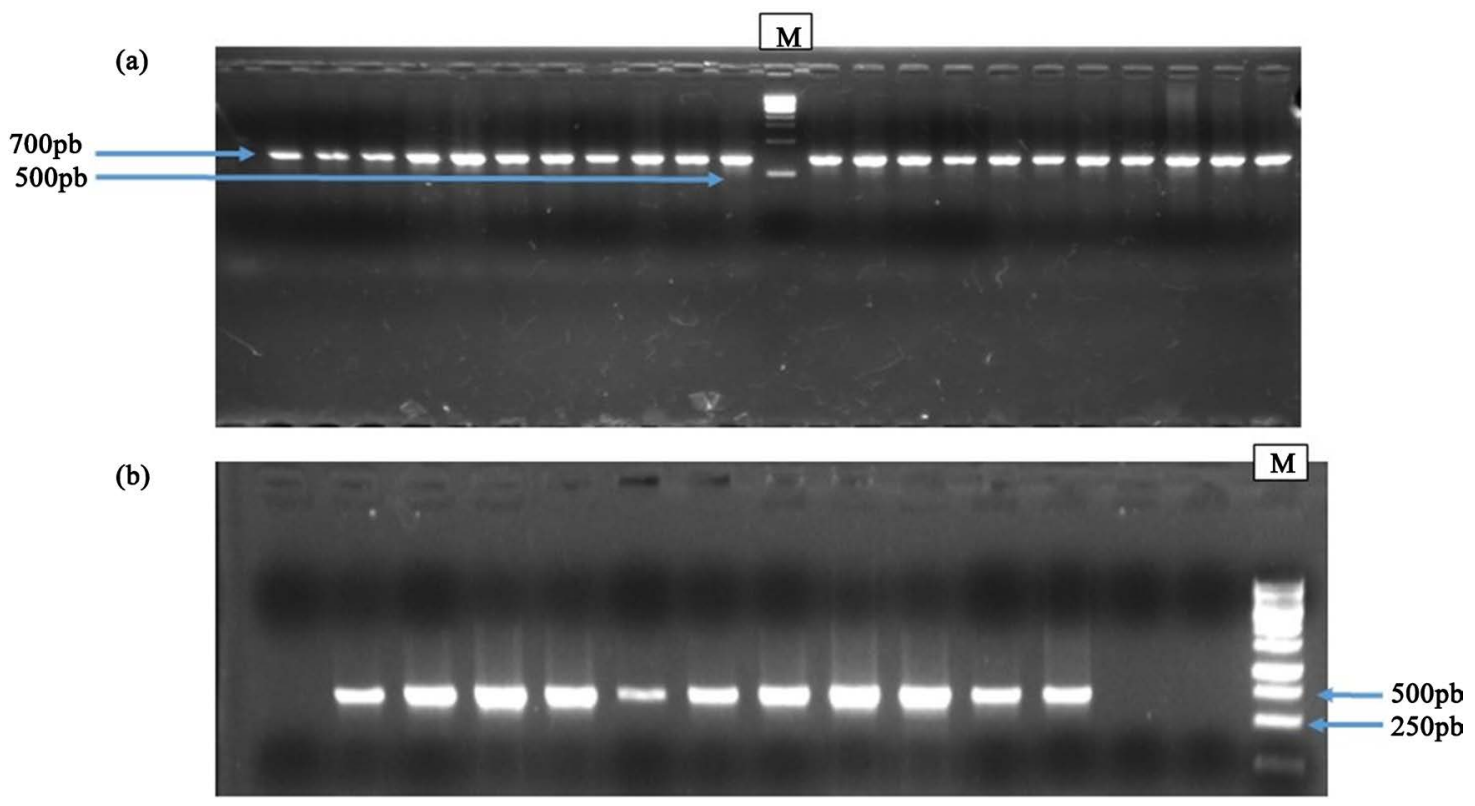

Figure 1. Examples of electrophoretic profiles showing the PCR results of SET 8 and TP53 genes. (a) Amplification of SET8 gene locus, Lane M: Molecular marker $1 \mathrm{~kb}$; (b) Amplification of TP53 gene locus, Lane M: Molecular marker $100 \mathrm{bp}$.
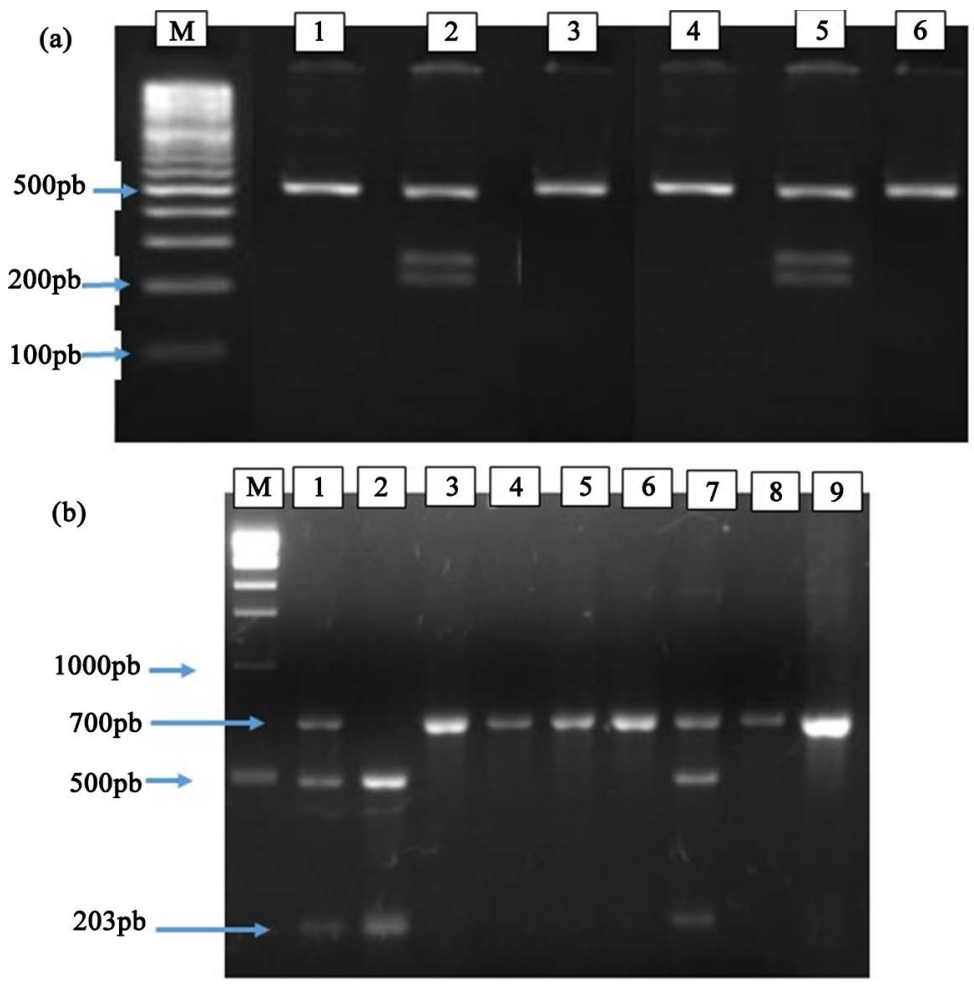

Figure 2. Examples of electrophoretic profiles showing the separation of PCR-RFLP products of SET8 and TP53. (a) polymorphisms of TP53 gene locus. Lane M: Molecular marker $100 \mathrm{pb}$; Lanes 1, 3, and 4, CC homozygous mutant (500 bp); lanes 2, and 5, CG heterozugous genotype (500, 286, and $214 \mathrm{bp}$ ), Lane 6: undigested band. (b) Polymorphism of SET8 gene locus. Lane M: Molecular marker $1 \mathrm{~kb}$; Lane 3, 4, 5, 6 and 8, CC homozygous Wild type (700 bp); lanes 1, and 7, CT heterozygous genotype (500, 497, 203 bp), lanes 2, TT homozygous mutant (497 and 203 bp); Lane 9; undigested band. 
At the TP53 gene locus, 61 (54.95\%) cases were homozygote wild-type with CC genotype while 50 (45.05\%) were heterozygote with CG genotype. Amongst the 224 controls, 159 (70.98\%) were homozygote wild-type (CC) while 65 (29.02\%) were heterozygote (CG). No patient or control was found with a profile corresponding to homozygote mutant (GG genotype) (Table 3).

Within the entire population, the SET8 locus had allelic frequencies of $91.49 \%$ $(613 / 670)$ for the $\mathrm{C}$ allele and $8.51 \%$ (57/670) for $\mathrm{T}$. In patients with breast cancer, the allelic frequencies for alleles $\mathrm{C}$ and $\mathrm{T}$ of the same locus were $93.69 \%(208 / 222)$ and $6.31 \%(14 / 222)$ respectively. In the controls, the allelic frequencies were $90.40 \%$ (405/448) and 9.60\% (43/448) for the $\mathrm{C}$ and $\mathrm{T}$ alleles, respectively (Table 4).

For the TP53 locus, the alleles C and G had the frequencies of $82.84 \%$ (555/ $670)$ and $17.16(115 / 670)$ respectively in the general population. Among patients, the TP53 locus had the frequencies of $77.48 \%(172 / 222)$ for allele $\mathrm{C}$ and $22.52 \%$ $(50 / 222)$ for $G$. In the controls, the allelic frequencies were $85.49 \%$ (383/448) for alleles C and 14.51\% (65/448) for G (Table 4).

\subsection{Association Study Performed on the Whole Population}

At the SET8 gene locus, the overall population as well as different subpopulations were in HWE $(\mathrm{p}=1)$. No significant difference was observed at this locus when the allelic and genotypic frequencies were compared between patients and controls.

Table 3. Genotypic frequencies at SET8 and TP53 loci in the entire population.

\begin{tabular}{|c|c|c|c|c|c|c|c|c|}
\hline Genes & Loci & Genotype & $\begin{array}{c}\text { Case } \\
(\mathrm{N}=111) \\
(\%)\end{array}$ & $\begin{array}{c}\text { Control } \\
(\mathrm{N}=224) \\
(\%)\end{array}$ & $\mathbf{P}$ & OR (CI 95\%) & Bonf & $* \mathrm{P}$ \\
\hline \multirow[t]{4}{*}{ SET8 } & rs16917496 & $\mathrm{CC}$ & 97 (87.39) & $183(81.70)$ & - & - & - & \multirow{3}{*}{0.147} \\
\hline & & $\mathrm{CT}$ & $14(12.61)$ & $39(17.41)$ & 0.24 & $1.48(0.76-2.85)$ & 1 & \\
\hline & & TT & $0(0.00)$ & $2(0.89)$ & 0.53 & $2.66(0.13-55.89)$ & 1 & \\
\hline & & $\mathrm{CT}+\mathrm{TT}$ & $14(12.61)$ & $41(18.30)$ & 0.1881 & $1.5523(0.80-2.99)$ & 0.3 & - \\
\hline \multirow[t]{2}{*}{$T P 53$} & rs 1042522 & $\mathrm{CC}$ & $61(54.95)$ & $159(70.98)$ & - & - & - & \multirow{2}{*}{0.0036} \\
\hline & & CG & $50(45.05)$ & $65(29.02)$ & 0.004 & $0.5(0.311-0.798)$ & 0.008 & \\
\hline
\end{tabular}

*P-value for Cochran-Armitage trend test; Bonf: Bonferroni; P: Nominal p unadjusted asymptotic probability value; OR: odds ratio; Confidence Interval at $95 \%$.

Table 4. Allelic frequencies at SET8 and TP53 loci in the entire population.

\begin{tabular}{|c|c|c|c|c|c|c|c|}
\hline Genes & Loci & Alleles & Case (\%) & Control (\%) & $\mathbf{P}$ & OR $(95 \% \mathrm{CI})$ & Bonf \\
\hline \multirow[t]{2}{*}{ SET8 } & rs16917496 & $\mathrm{C}$ & $208(93.7)$ & $405(90.4)$ & - & - & \\
\hline & & $\mathrm{T}$ & $14(6.3)$ & $43(9.6)$ & 0.15 & $0.629(0.33-1.18)$ & 0.301 \\
\hline \multirow[t]{2}{*}{ TP53 } & rs1042522 & $\mathrm{C}$ & $172(77.5)$ & $383(85.5)$ & - & - & - \\
\hline & & G & $50(22.5)$ & $65(14.5)$ & 0.00389 & $2.005(1.25-3.215)$ & 0.007 \\
\hline
\end{tabular}

Bonf: Bonferroni; P: Nominal p unadjusted asymptotic probability value; OR: odds ratio; CI: Confidence Interval. 
For TP53 gene, the allelic frequencies were not in HWE $(\mathrm{p}$-value $=0.021)$ when the entire population was considered. In this context, results of association studies cannot be considered despite the fact that a significantly increased risk of BC development was observed for the $\mathrm{G}$ allele (Table 4) (OR, 2.002; CI 95\%, 1.25 - 3.215; p-value $=0.00389)$ and CG genotype (Table 3) $(\mathrm{OR}, 0.5$; CI 95\%, $0.311-0.798 ; \mathrm{p}$-value $=0.004)$. When the population was stratified into ethno-linguistic subgroups and according to the menopausal status, the allelic frequencies were in HWE for the Bantu ( $\mathrm{p}$-value $=0.5859)$, Semi-bantu ( $\mathrm{p}$-value = 0.1428 ) ethno-linguistic groups, premenopausal ( $\mathrm{p}$-value $=0.1$ ) and postmenopausal $(\mathrm{p}$-value $=0.5841)$ women, respectively. The Sudano-Sao ethno-linguistic subgroup was not in HWE $(\mathrm{p}=0.0373)$ (Table 5). Data presented in Table 5 shows detailed results of HWE values when the population was stratified into ethno-linguistic groups.

The heterogeneous nature of the studied population formed by several ethno-linguistic subgroups has an impact on the HWE. For these reasons (various ethno-linguistic groups and the deviation of HWE in the entire population), additional analyses were performed with the Cochran-Mantel-Haentszel test (CMH) that takes into account the population stratification. For these analyses, the population was stratified on the basis of ethno-linguistic groups and the menopausal status. During these analyses, the Sudano-Sao subgroup was excluded.

\subsection{Association Study Performed on the Stratified Population}

Data used in the CMH test included 328 participants (105 BC patients and 223 controls) from Bantu and Semi-bantu ethno-linguistic groups; the Sudano-sao group being excluded. With the $\mathrm{CMH}$ test, no significant association was observed between the polymorphisms at SNPs of SET8 and TP53 genes and the risk of developing $\mathrm{BC}$ in different ethno-linguistic groups. The minor allele $\mathrm{T}$ at the SET8 locus was not significantly associated (unadjusted $\mathrm{p}=0.096, \mathrm{X}^{2}=2.777$, adjusted $\mathrm{p}=0.1913$ ) with $\mathrm{BC}$ development. For the TP53 locus, the minor allele

Table 5. Variations of HWE values according to loci and ethno-linguistic groups.

\begin{tabular}{cccccc}
\hline Subpopulations & Genes & Loci & Cases & Controls & HWE \\
\hline Bantu & SET8 & rs16917496 & 33 & 82 & 0.4922 \\
& TP53 & rs1042522 & & & 0.5859 \\
Semi-bantu & SET8 & rs16917496 & 72 & 182 & 1 \\
Sudano-Sao & TP53 & rs1042522 & & & 0.1428 \\
& $S E 78$ & rs16917496 & 6 & 1 & 1 \\
Premenopausal & TP53 & rs1042522 & & & 0.0373 \\
& SET8 & rs16917496 & 77 & 195 & 0.6764 \\
Postmenopausal & TP53 & rs1042522 & & & 0.1 \\
& SET8 & rs16917496 & 34 & 29 & 1 \\
& $T P 53$ & rs1042522 & & & 0.5841 \\
\hline
\end{tabular}


G was not also significantly associated (unadjusted $\mathrm{p}=0.394, \mathrm{X}^{2}=0.727$, adjusted $\mathrm{p}=0.787$ ) with $\mathrm{BC}$ development. Regarding the menopausal status, the $\mathrm{CMH}$ test revealed no significant association at $S E T 8$ locus (OR, 0.547, 95\% CI, $0.2764-1.085$; unadjusted $\mathrm{p}=0.089$; adjusted $\mathrm{p}=0.1792)$ as well as TP53 (OR, $1.245,95 \%$ CI $0.7318-2.119$; and unadjusted $\mathrm{p}=0.412$; adjusted $\mathrm{p}=0.8252)$ locus. With $\mathrm{CMH} 2$ test, no significant difference was observed in allelic frequencies between different subpopulations either at $S E T 8$ locus (p-value $=0.181$ ) or $T P 53$ locus ( $\mathrm{p}$-value $=0.485$ ).

\subsection{Association Study Performed on Each Subpopulation}

Due to the fact that the $\mathrm{CMH}$ test did not show any significant association with the different subpopulations, each of them was analyzed independently with the logistic regression model by considering only the subpopulations that were in HWE.

\subsection{Association Study Performed According to Menopausal Status}

The CT genotype of SET8 gene was significantly associated with increased risk of BC development in premenopausal women (OR, 2.93 95\% CI, 0.12 - 0.81; and unadjusted $\mathrm{p}=0.03$; adjusted $\mathrm{p}=0.042$ ) (Table 7). After performing the association studies with the dominant model between $\mathrm{CT}$ and TT genotypes versus CC genotype of $S E T 8$, the CT and TT genotypes were significantly (OR, $3.195 \% \mathrm{CI}$, 1.17 - 8.24; unadjusted $\mathrm{p}$ value $=0.02$ and adjusted $\mathrm{p}=0.04)$ associated the increase risk BC development in premenopausal compared to CC genotype. With the allelic test, the minor allele $\mathrm{T}$ of $S E T 8$ gene was significantly associated with decrease risk of developing $\mathrm{BC}$ compared to the $\mathrm{C}$ allele (OR, 0.327, 95\% CI, $0.125-0.852$; and unadjusted $\mathrm{p}=0.02$; adjusted $\mathrm{p}=0.044)($ Table 6$)$. This result indicates that the $\mathrm{T}$ allele of $S E T 8$ gene has a protective effect on the development of BC in premenopausal women. In postmenopausal women, no significant association was observed between polymorphism at SET8 and the risk of developing BC at the genotypic (Table 7) and allelic (Table 6) levels.

For TP53 gene, the minor allele G showed a significant (OR, 2.533, 95\% CI, 1.455 - 4.408; and unadjusted $\mathrm{p}=0.001$; adjusted $\mathrm{p}=0.002$ ) association with an increased risk of BC development in premenopausal women (Table 6). However, the logistic regression model revealed that the CG genotype was significantly associated with decreased (OR, 0.39, 95\% CI, $0.23-0.69$; and unadjusted $\mathrm{p}=$ 0.001 ; adjusted $\mathrm{p}=0.002$ ) the risk of $\mathrm{BC}$ development.

\subsection{Association Studies According to Different Ethno-Linguistic Groups}

Table 6 and Table 7 illustrate the allelic and genotypic frequency distribution at TP53 and SET8 loci in population stratified by ethno-linguistic groups and menopausal status. In different ethno-linguistic groups, no significant association was observed between polymorphisms at TP53 and SET8 loci and the risk of BC 
A. A. Z. Tiofack et al.

Table 6. Allelic frequencies at SET8 and TP53 loci in populations stratified by ethno-linguistic groups and menopausal status.

\begin{tabular}{|c|c|c|c|c|c|c|c|}
\hline Gene & Subpopulations & alleles & Cases (\%) & Controls (\%) & $\mathrm{P}$-value & OR (95\% CI) & Bonf \\
\hline \multirow[t]{8}{*}{ SET8 rs 16917496} & Premenopausal & $\mathrm{C}$ & $141(95.27)$ & $358(92.27)$ & - & - & - \\
\hline & & $\mathrm{T}$ & $5(3.42)$ & $38(9.79)$ & 0.02 & $0.327(0.125-0.852)$ & 0.044 \\
\hline & Postmenopausal & $\mathrm{C}$ & $56(87.5)$ & $53(91.38)$ & - & - & - \\
\hline & & $\mathrm{T}$ & $8(12.5)$ & $5(8.62)$ & 0.462 & $1.6(0.4573-5.598)$ & 0.924 \\
\hline & Bantu & $\mathrm{C}$ & $61(92.42)$ & $73(89.02)$ & - & - & - \\
\hline & & $\mathrm{T}$ & $5(7.58)$ & $9(10.98)$ & 0.4967 & $0.6774(0.2203-2.083)$ & 0.9935 \\
\hline & Semi-Bantu & $\mathrm{C}$ & $136(94.44)$ & $183(84.33)$ & - & - & - \\
\hline & & $\mathrm{T}$ & $8(5.56)$ & $34(15.67)$ & 0.1594 & $0.5591(0.2488-1.257)$ & 0.3188 \\
\hline \multirow[t]{8}{*}{ TP53 rs 1042522} & Premenopausal & $\mathrm{C}$ & $102(69.86)$ & $332(85.57)$ & - & - & - \\
\hline & & G & $37(25.34)$ & $56(14.43)$ & 0.001 & $2.533(1.455-4.408)$ & 0.002 \\
\hline & Postmenopausal & $\mathrm{C}$ & $57(89.06)$ & $50(86.21)$ & - & - & - \\
\hline & & G & $7(10.94)$ & $8(13.79)$ & 0.6056 & $0.735(0.2284-2.365)$ & 1 \\
\hline & Bantu & $\mathrm{C}$ & $50(75.76)$ & $73(89.02)$ & - & - & - \\
\hline & & G & $16(24.24)$ & $9(10.98)$ & 0.1102 & $3.346(1.22-9.155)$ & 0.2205 \\
\hline & Semi-Bantu & $\mathrm{C}$ & $116(80.55)$ & $309(84.89)$ & - & - & - \\
\hline & & G & $28(19.44)$ & $55(15.11)$ & 0.1855 & $1.469(0.83-2.598)$ & 0.4 \\
\hline
\end{tabular}

Table 7. Genotypic frequencies at SET8 and TP53 loci in populations stratified by ethno-linguistic groups and menopausal status.

\begin{tabular}{|c|c|c|c|c|c|c|c|c|}
\hline Gene variants & Subpopulations & Genotypes & Cases & Controls & p-value & OR (95\% CI) & Bonf & ${ }^{*} \mathrm{p}$-value \\
\hline \multirow{15}{*}{$\begin{array}{c}S E T 8 \\
\text { rs } 16917496\end{array}$} & \multirow[t]{4}{*}{ Premenopausal } & $\mathrm{CC}$ & $68(93.15)$ & $158(81.44)$ & - & - & - & \multirow[t]{4}{*}{0.0166} \\
\hline & & $\mathrm{CT}$ & $5(6.85)$ & $34(17.53)$ & 0.03 & $2.93(1.1-7.8)$ & 0,042 & \\
\hline & & $\mathrm{TT}$ & $0(0.00)$ & $2(1.03)$ & 0.62 & $2.16(0.22-221.14)$ & 1 & \\
\hline & & $\mathrm{CT}+\mathrm{TT}$ & $5(6.85)$ & $36(18.56)$ & 0.018 & $3.1(1.21-7.93)$ & 0.036 & \\
\hline & \multirow[t]{3}{*}{ Postmenopausal } & $\mathrm{CC}$ & $24(75)$ & $24(82.76)$ & - & - & - & \multirow[t]{3}{*}{0.4599} \\
\hline & & $\mathrm{CT}$ & $8(25)$ & $5(17.24)$ & 0.46 & $0.63(0.19-2.1)$ & 1 & \\
\hline & & $\mathrm{TT}$ & $0(0.0)$ & $0(0.0)$ & 1 & $1(0.06-16.9)$ & 1 & \\
\hline & \multirow[t]{4}{*}{ Bantu } & $\mathrm{CC}$ & $28(84.85)$ & $33(80.49)$ & - & - & - & \multirow[t]{4}{*}{0.4937} \\
\hline & & $\mathrm{CT}$ & $5(15.15)$ & $7(17.07)$ & 0.79 & $1.19(0.35-3.98)$ & 1 & \\
\hline & & $\mathrm{TT}$ & $0(0.0)$ & $1(2.44)$ & 0.56 & $2.6(0.22-29.61)$ & 1 & \\
\hline & & $\mathrm{CT}+\mathrm{TT}$ & $5(15.15)$ & $8(19.51)$ & 0.62 & $1.3(0.42-4.43)$ & & \\
\hline & \multirow[t]{4}{*}{ Semi-bantu } & $\mathrm{CC}$ & $64(88.89)$ & $149(81.87)$ & - & - & - & \multirow[t]{4}{*}{0.1546} \\
\hline & & $\mathrm{CT}$ & $8(11.11)$ & $32(17.58)$ & 0.20 & $1.72(0.77-3.86)$ & 0.4 & \\
\hline & & $\mathrm{TT}$ & $0(0.0)$ & $1(0.55)$ & 0.88 & $1.3(0.12-14.53)$ & 1 & \\
\hline & & $\mathrm{CT}+\mathrm{TT}$ & $8(11.11)$ & $33(18.13)$ & 0.17 & $1.78(0.79-3.98)$ & 0.2 & \\
\hline \multirow[t]{2}{*}{ TP53 rs 1042522} & Premenopausal & $\mathrm{CC}$ & $36(49.32)$ & $138(71.13)$ & - & - & - & \multirow[t]{2}{*}{0.00085} \\
\hline & & CG & $37(50.68)$ & $56(28.87)$ & 0.001 & $0.39(0.23-0.69)$ & 0.002 & \\
\hline
\end{tabular}




\section{Continued}

\begin{tabular}{cccccccc} 
Postmenopausal & CC & $25(78.12)$ & $21(72.41)$ & - & - & - & 0.6049 \\
\multirow{2}{*}{ Bantu } & CG & $7(21.88)$ & $8(27.59)$ & 0.61 & $1.36(0.43-4.24)$ & 1 & \\
& CC & $17(66.67)$ & $32(82.93)$ & - & - & - & 0.11 \\
\multirow{3}{*}{ Semi-bantu } & CG & $16(33.33)$ & $9(17.07)$ & 0.18 & $3.346(1.22-9.155)$ & 1 & \\
& CC & $44(61.11)$ & $127(69.78)$ & - & - & - & 0.2 \\
& CG & $28(38.89)$ & $55(30.22)$ & 0,184 & $0.7(0.386-1.199)$ & 0.4 &
\end{tabular}

${ }^{*} \mathrm{p}$-value Cochran-Armitage trend test; Bonf: Bonferroni; p-value: Nominal p unadjusted asymptotic probability value; OR: odds ratio; Confidence Interval at $95 \%$.

Table 8. Relationship between SET8, TP53 and known clinicopathological variables

\begin{tabular}{|c|c|c|c|c|c|c|c|}
\hline \multirow{2}{*}{$\begin{array}{l}\text { Clinicopathological } \\
\text { variables }\end{array}$} & \multirow{2}{*}{$\begin{array}{c}\text { Number }(n= \\
111)\end{array}$} & \multicolumn{2}{|c|}{ Genotype (\%) SET8 } & \multirow[t]{2}{*}{$\mathrm{p}$-value } & \multicolumn{2}{|c|}{ Genotype (\%) TP53 } & \multirow[t]{2}{*}{ p-value } \\
\hline & & $\mathrm{CC}$ & TC & & $\mathrm{CC}$ & CG & \\
\hline Age (years) & & & & 1 & & & 0.09 \\
\hline$\leq 40$ & 53 & $46(86.79)$ & $7(13.21)$ & & $34(64.15)$ & $19(35.85)$ & \\
\hline$>40$ & 58 & $51(87.93)$ & $7(12.07)$ & & $46(79.31)$ & $12(20.69)$ & \\
\hline Site of Breast & & & & 0,611 & & & 0.72 \\
\hline Left & 53 & $45(84.91)$ & $8(15.09)$ & & $40(75.47)$ & $13(24.52)$ & \\
\hline Right & 54 & $48(88.89)$ & $6(11.11)$ & & $37(68.52)$ & $17(31.48)$ & \\
\hline Bilateral & 4 & $4(100)$ & $0(0.00)$ & & $3(75)$ & $1(25)$ & \\
\hline Tumor stage & & & & 1 & & & 0.70 \\
\hline I, II & 9 & $8(88.89)$ & $1(11.11)$ & & $6(66.67)$ & $3(33.33)$ & \\
\hline III, IV & 102 & $89(87.25)$ & $13(12.75)$ & & $74(72.55)$ & $28(27.45)$ & \\
\hline Lymph node & & & & 0.37 & & & 0.51 \\
\hline Yes & 71 & $60(84.51)$ & $11(15.49)$ & & $53(74.65)$ & $18(25.35)$ & \\
\hline No & 40 & $37(92.5)$ & $3(7.5)$ & & $27(67.5)$ & $13(32.5)$ & \\
\hline Metastasis & & & & 1 & & & 0.66 \\
\hline Yes & 41 & $36(87.80)$ & $5(12.19)$ & & $31(75.61)$ & $10(24.39)$ & \\
\hline No & 70 & $61(87.14)$ & $9(12.86)$ & & $49(70)$ & $21(30)$ & \\
\hline
\end{tabular}

development between women with and without breast cancer.

Additional association studies that take into consideration the clinical and pathological characteristics of the disease revealed no significant association between the polymorphisms at SET8 and TP53 loci and the risk of developing different clinical evolution of breast cancer in the studied population (Table 8).

\subsection{Frequencies of Combined Genotypes}

The combination of CC genotype of SET8 and GC genotype of TP53 revealed a significant protective effect $(\mathrm{OR}=0.46,95 \% \mathrm{CI}: 0.24-0.91$, $\mathrm{p}$-value $=0.024)$ for $\mathrm{BC}$ development with the significant enlargement in healthy controls compared to BC patients. The other genotype combinations didn't show any association with BC development (Table 9). 
Table 9. SET8 and TP53 Genotype Combination Distribution in BC Cases and Controls in premenopausal.

\begin{tabular}{ccccc}
\hline SET8 and TP53 & Cases, $\mathbf{N}=77(\%)$ & Controls, $\mathbf{N}=195(\%)$ & p-value & OR (95\% CI) \\
\hline CC and CC & $52(67.53)$ & $135(69.23)$ & - & - \\
CC and CG & $20(25.97)$ & $24(12.31)$ & 0.024 & $0.46(0.24-0.91)$ \\
CT and CC & $3(3.90)$ & $23(11.79)$ & - & - \\
CT and CG & $2(2.60)$ & $11(5.64)$ & 0.735 & $0.72(0.10-4.91)$ \\
TT and CC & $0(0.00)$ & $2(1.03)$ & - & - \\
TT and CG & $0(0.00)$ & $0(0.00)$ & 0.524 & $0.2(0.001-28.47)$ \\
\hline
\end{tabular}

\section{Discussion}

In this study, polymorphisms in two BC-related genes (SET8 and TP53) were investigated for their association with breast cancer development in Cameroonian women. Our results revealed that the polymorphism at $S E T 8$ gene locus is significantly associated with BC development in premenopausal women. The minor $\mathrm{T}$ allele was significantly (OR, $0.31,95 \% \mathrm{CI}, 0.12-0.81$; and unadjusted $\mathrm{p}$ $=0.02$; adjusted $\mathrm{p}$-value $=0.03$ ) associated with a reduced risk of $\mathrm{BC}$ development in premenopausal women. These results are in agreement with those reported in premenopausal Chinese women with BC [23]. Moreover, this allele has been associated with an increased risk of epithelial ovarian cancer among Chinese women [41]. The discrepancies observed in the association of $\mathrm{T}$ allele of SET8 with the development of different cancers could result from the cancer type and/or the genetic diversity between the studied populations. This diversity can be illustrated by the differences in the allelic frequencies and linkage disequilibrium (LD) blocks among different ethnicities/races [42]. In Chinese and non-Hispanic white populations for instance, the allelic frequency for $\mathrm{T}$ allele is above $63 \%$ while in black African population, it is less than $12 \%$ according to the 1000 genomes project [43]. For these reasons, certain polymorphisms associated with cancer development at this locus and for a given population could not be reproduced in others [44] [45].

Compared to TT genotypes, the TC genotype of SET8 is significantly associated (OR, 3.08, 95\% CI, 1.15 - 8.19; adjusted $\mathrm{P}=0.04$ ) with an increased risk of $\mathrm{BC}$ development in premenopausal women. This finding does not corroborate results reported in Chinese premenopausal women where Song et al. [23] showed that the TC genotype seemed to reduce the risk of getting BC compared to TT and CC genotypes. The discrepancies between these results could be related to the differences in allele frequencies and the genetic differences between Cameroon and Chinese populations. With evidence that the $\mathrm{T}$ allele reduces the risk of $\mathrm{BC}$ development in premenopausal women, unlike the TC genotype which carries both the $\mathrm{T}$ and $\mathrm{C}$ alleles, a dominant model was performed for over-dominance of the TC genotype over the genotype TT in comparison with the CC genotype. Using this model (CT + TT vs CC), we found an increased risk of breast 
cancer in individuals with both genotypes (OR, 3.26, 95\% CI, 1.23 to 8.65; and unadjusted $\mathrm{p}=0.02$; adjusted $\mathrm{p}=0.04$ ). This could be explained by the low frequency of the TT genotype in cases and controls. However, our results are in line with those demonstrating that polymorphism at SET8 locus increased the risk of prostate cancer in the co-dominant (i.e.: TC vs TT and CC vs TT) and dominant models of inheritance tested [46].

Although some investigations suggested no association between polymorphism at TP53 locus of codon 72 and BC development in Africa [19] [23] [47] [48], other studies reported some associations with a variety of human cancers including BC [49] [50] [51]. When our analyses were undertaken on the entire population without stratification, no association was found between polymorphism at TP53 locus with BC development neither with the Cochran-Mantel-Haenszel $(\mathrm{CMH})$ nor with the Cochran-Armitage trend test. These results are in line with those reported elsewhere in Africa where, whatever the menopausal status, no association was reported between polymorphism at rs1042522 of TP53 and the risk of BC development [19] [48]. However, it is important to point out that the allele frequencies were not in HWE at this locus when the entire population was analyzed. This deviation of HWE could result from the heterogeneity of our studied population formed by three different ethno-linguistic groups with some genetic differences. This heterogeneity induces a deviation from HWE resulting probably from the Wahlund effect [52] which is caused by some variations in allele frequency among subpopulations [52] [53] [54]. Indeed, in different regions of Cameroon, the populations are grouped according to their ethno-linguistic groups with very few probabilities of inter-marriage between people from different ethno-linguistic groups. This social behavior could induce Wahlund effect resulting from the lack of genetic exchange between populations of different ethno-linguistic groups [30]. Consequently, an increase in the inbreeding rate, a strong genetic drift and a decrease of the genetic diversity could be observed within and between these populations [55] [56] [57]. The small sample size of Sudano-sao ethno-linguistic groups could also increase the inbreeding effect on the high variance of allele frequencies. The heterogeneous structure of our studied population may impale a strong genetic drift that changes the gene ratio of population in a random manner. Moreover, the errors impaled by genotyping methods could increase the heterozygote frequency and the observation of some mutant alleles [58] [59] [60] [61]. These hypotheses are strengthened by the differences observed for the values of HWE within and between different ethno-linguistic groups (S5 Table). All these factors could bias results of association studies and consequently, a reduction of the power of this study.

When the Sudano-sao ethno-linguistic group was excluded because it was not in HWE, an association was found between polymorphism at TP53 locus and the risk of $\mathrm{BC}$ development in premenopausal women. In fact, the G allele of TP53 locus is significantly associated (OR, 2.533, 95\% CI, 1.455 - 4.408; adjusted $\mathrm{P}=0.002$ ) with risk of $\mathrm{BC}$ among premenopausal Cameroonian women. These 
results are in line with those reported in Caucasian patients where polymorphism at the same locus seemed to increase risk of BC among premenopausal women [62]. However, some studies have suggested that there is no association between the rs 1042522 variant and the development of BC in Africa, whatever the menopausal status [19] [47]. The discrepancies between association studies involving this SNP could be explained by the genetic variability of the African population made up of various ethno-linguistic groups characterized by a diversity of genetic background [21] [62].

Although the CG genotype of TP53 has not been implicated in premenopausal BC susceptibility [48], results (adjusted p-value of 0.002 and an OR of 0.39) of our study revealed its association with a reduced risk of developing $\mathrm{BC}$ in premenopausal women. These results contrast those of Cherdyntseva et al. [61] reporting that CG genotype seemed to increase the risk of $\mathrm{BC}$ in premenopausal Caucasian patients. Moreover, the GC genotype of TP53 showed a protective effect against retinoblastoma invasion [63]. The differences observed in these association studies could be related to differences in genotype frequencies between various populations and the type of cancer considered. In our study, both cases and controls showed a high prevalence of $\mathrm{C}$ allele compared to $\mathrm{G}$ allele and the lack of GG genotype. Indeed, Brenna et al. [64] had shown that the frequency of $\mathrm{G}$ allele increases with latitude, while the $\mathrm{C}$ allele shows the opposite effect. Moreover, several studies reported that polymorphism at SNP rs1042522 is balanced by natural selection [65] [66]. They also reported that the frequency of $\mathrm{C}$ allele increases in a linear manner in multiple populations as they are near the equator, with around $60 \%$ in people of African descent and $17 \%-34 \%$ in those of Caucasian descent [65] [66]. These variations in the allelic and genotypic frequencies according to geographical position of the studied populations could partly explain the rarity of G allele and GG genotype in Cameroon and therefore, their association with the risk of breast cancer development in Cameroonian premenopausal women.

In our study, the combination of CC genotype of $S E T 8$ with CG genotype of $T P 53$ has a significant protective effect $(\mathrm{OR}=0.46,95 \% \mathrm{CI}: 0.24-0.91, \mathrm{P}=$ $0.024)$ against $\mathrm{BC}$ development in premenopausal women. These results do no corroborate with those obtained in Chinese population where individuals with the same combined genotypes had a high risk of developing BC at an early age [23]. These results suggest that SET8 and TP53 gene variants may interact in BC development. They are in line with observations of Yang et al. [25] providing evidence that there is a gene-gene interaction between SET8 and TP53 polymorphisms and the risk of cervical cancer. Indeed, past investigations revealed the contribution of cancer-related SET8 mutants with p53 in the installation of DNA-damage signaling and senescence in primary human cells [67]. TP53 is regulated by monomethylation at K382 by SET8, which might render TP53 gene inert in part by preventing acetylation at K382 [67]. Further studies with large sample sizes are needed to confirm our findings. 


\section{Conclusion}

This study showed a significant association between the polymorphisms in the 3'-UTR of SET8 and in the codon 72 of TP53 genes and the risk of developing BC in premenopausal Cameroonian women. The association of SET8 and TP53 polymorphisms with the risk of $\mathrm{BC}$ suggests a multiplicative gene-gene interaction. Further studies are warranted to elucidate the role of genetic polymorphisms in breast carcinogenesis in Cameroon.

\section{Data Availability}

The data used to support the findings of this study are available from the corresponding author upon request.

\section{Acknowledgements}

We thank the General Hospital of Douala and the "Cancer Center" of clinic St. Joseph of Fouda of Yaounde for collecting the clinical samples. The authors also thank the women who participated in this study. They thank the dedicated team of study research assistants, notably Prof Samuel Takongmo, Prof. Adamou Fewou, Prof. Charlotte T. Nguefack, Prof Theophile N. Nana, and Dr Sidonie N. Ananga, for their contribution in the inclusion of participants.

\section{Conflicts of Interest}

The authors declare no conflicts of interest regarding the publication of this paper.

\section{References}

[1] Bray, F., Ferlay, J., Soerjomataram, I., Siegel, R.L., Torre, L.A. and Jemal, A. (2018) Global Cancer Statistics 2018: GLOBOCAN Estimates of Incidence and Mortality Worldwide for 36 Cancers in 185 Countries. CA: A Cancer Journal for Clinicians, 68, 394-424. https://doi.org/10.3322/caac.21492

[2] Eng, A., McCormack, V. and dos-Santos-Silva, I. (2014) Receptor-Defined Subtypes of Breast Cancer in Indigenous Populations in Africa: A Systematic Review and Meta-Analysis. PLoS Medicine, 11, e1001720. https://doi.org/10.1371/journal.pmed.1001720

[3] Galukande, M., Wabinga, H., Mirembe, F., Karamagi, C. and Asea, A. (2014) Molecular Breast Cancer Subtypes Prevalence in an Indigenous Sub Saharan African Population. The Pan African Medical Journal, 17, 249. https://doi.org/10.11604/pamj.2014.17.249.3305

[4] Jedy-Agba, E., McCormack, V., Adebamowo, C. and Dos-Santos-Silva, I. (2016) Stage at Diagnosis of Breast Cancer in Sub-Saharan Africa: A Systematic Review and Meta-Analysis. The Lancet Global Health, 4, e923-e935. https://doi.org/10.1016/S2214-109X(16)30259-5

[5] McKenzie, F., Zietsman, A., Galukande, M., Anele, A., Adisa, C., Parham, G., Pinder, L., Dos Santos Silva, I. and McCormack, V. (2018) Breast Cancer Awareness in the Sub-Saharan African ABC-DO Cohort: African Breast Cancer-Disparities in Outcomes Study. Cancer Causes and Control, 29, 721-730. 
https://doi.org/10.1007/s10552-018-1047-7

[6] Sawe, R.T., Kerper, M., Badve, S., Li, J., Sandoval-Cooper, M., Xie, J., Shi, Z., Patel, K., Chumba, D., Ofulla, A., Prosperi, J., Taylor, K., Stack, M.S., Mining, S. and Littlepage, L.E. (2016) Aggressive Breast Cancer in Western Kenya Has Early Onset, High Proliferation, and Immune cell Infiltration. BMC Cancer, 16, 204. https://doi.org/10.1186/s12885-016-2204-6

[7] Adebamowo, C.A. and Adekunle, O.O. (1999) Case-Controlled Study of the Epidemiological Risk Factors for Breast Cancer in Nigeria. The British Journal of Surgery, 86, 665-668. https://doi.org/10.1046/j.1365-2168.1999.01117.x

[8] Balekouzou, A., Yin, P., Afewerky, H.K., Bekolo, C., Pamatika, C.M., Nambei, S.W., Djeintote, M., Doui Doumgba, A., Mossoro-Kpinde, C.D., Shu, C., Yin, M., Fu, Z., Qing, T., Yan, M., Zhang, J., Chen, S., Li, H., Xu, Z. and Koffi, B. (2017) Behavioral Risk Factors of Breast Cancer in Bangui of Central African Republic: A Retrospective Case-Control Study. PLoS ONE, 12, e0171154.

https://doi.org/10.1371/journal.pone.0171154

[9] Essiben, F., Foumane, P., Meka, E.N.U., Soh, P.S., Sama, J.D., Osogo, E. and Mboudou, E.T. (2016) Risk Factors for Breast Cancer: A Case-Control Study of 315 Women Followed in the Gynecology and Oncology Departments of Two University Teaching Hospitals in Yaounde, Cameroon. Open Journal of Obstetrics and Gynecology, 6, 676-688. https://doi.org/10.4236/ojog.2016.612085

[10] Clarke, C.A., Keegan, T.H., Yang, J., Press, D.J., Kurian, A.W., Patel, A.H. and Lacey, J.V. (2012) Age-Specific Incidence of Breast Cancer Subtypes: Understanding the Black-White Crossover. Journal of the National Cancer Institute, 104, 1094 1101. https://doi.org/10.1093/jnci/djs264

[11] Fregene, A. and Newman, L.A. (2005) Breast Cancer in Sub-Saharan Africa: How Does It Relate to Breast Cancer in African-American Women? Cancer, 103, 1540 1550. https://doi.org/10.1002/cncr.20978

[12] Mavaddat, N., Antoniou, A.C., Easton, D.F. and Garcia-Closas, M. (2010) Genetic Susceptibility to Breast Cancer. Molecular Oncology, 4, 174-191. https://doi.org/10.1016/j.molonc.2010.04.011

[13] Gray, I.C., Campbell, D.A. and Spurr, N.K. (2000) Single Nucleotide Polymorphisms as Tools in Human Genetics. Human Molecular Genetics, 9, 2403-2408. https://doi.org/10.1093/hmg/9.16.2403

[14] Giacomini, K.M., Brett, C.M., Altman, R.B., Benowitz, N.L., Dolan, M.E., Flockhart, D.A., Johnson, J.A., Hayes, D.F., Klein, T., Krauss, R.M., Kroetz, D.L., McLeod, H.L., Nguyen, A.T., Ratain, M.J., Relling, M.V., Reus, V., Roden, D.M., Schaefer, C.A., Shuldiner, A.R., Skaar, T. and Pharmacogenetics Research Network (2007) The Pharmacogenetics Research Network: From SNP Discovery to Clinical Drug Response. Clinical Pharmacology and Therapeutics, 81, 328-345. https://doi.org/10.1038/sj.clpt.6100087

[15] Nicoloso, M.S., Sun, H., Spizzo, R., Kim, H., Wickramasinghe, P., Shimizu, M. Wojcik, S.E., Ferdin, J., Kunej, T., Xiao, L., Manoukian, S., Secreto, G., Ravagnani, F., Wang, X., Radice, P., Croce, C.M., Davuluri, R.V. and Calin, G.A. (2010) Single-Nucleotide Polymorphisms inside microRNA Target Sites Influence Tumor Susceptibility. Cancer Research, 70, 2789-2798. https://doi.org/10.1158/0008-5472.CAN-09-3541

[16] Deng, N., Zhou, H., Fan, H. and Yuan, Y. (2017) Single Nucleotide Polymorphisms and Cancer Susceptibility. Oncotarget, 8, 110635-110649.

https://doi.org/10.18632/oncotarget.22372

[17] Sellers, T.A., Huang, Y., Cunningham, J., Goode, E.L., Sutphen, R., Vierkant, R.A., 
Kelemen, L.E., Fredericksen, Z.S., Liebow, M., Pankratz, V.S., Hartmann, L.C., Myer, J., Iversen, E.S., Schildkraut, J.M. and Phelan, C. (2008) Association of Single Nucleotide Polymorphisms in Glycosylation Genes with Risk of Epithelial Ovarian Cancer. Cancer Epidemiology, Biomarkers and Prevention, 17, 397-404. https://doi.org/10.1158/1055-9965.EPI-07-0565

[18] Tiofack, Z.A.A., Simo, G., Ofon, E., Dina-Bell, E., Kamla, C.M., Ananga, S.N., Roger, T., Nana, T.N., Ngeufack, C.T., Fewou, A., Takongmo, S. and Lueong, S. (2020) The TP63 Gene Polymorphism rs17506395 Is Associated with Early Breast Cancer in Cameroon. Asian Pacific Journal of Cancer Prevention, 21, 2199-2208. https://doi.org/10.31557/APJCP.2020.21.8.2199

[19] Habyarimana, T., Attaleb, M., Mugenzi, P., Mazarati, J.B., Bakri, Y. and El Mzibri, M. (2018) Association of p53 Codon 72 Polymorphism with Breast Cancer in a Rwandese Population. Pathobiology, 85, 186-191. https://doi.org/10.1159/000481664

[20] Akkiprik, M., Sonmez, O., Gulluoglu, B.M., Caglar, H.B., Kaya, H., Demirkalem, P., Abacioglu, U., Sengoz, M., Sav, A. and Ozer, A. (2009) Analysis of p53 Gene Polymorphisms and Protein Over-Expression in Patients with Breast Cancer. Pathology Oncology Research, 15, 359-368. https://doi.org/10.1007/s12253-008-9129-6

[21] Thomas, M., Kalita, A., Labrecque, S., Pim, D., Banks, L. and Matlashewski, G. (1999) Two Polymorphic Variants of Wild-Type p53 Differ Biochemically and Biologically. Molecular and Cellular Biology, 19, 1092-1100. https://doi.org/10.1128/MCB.19.2.1092

[22] Sakamuro, D., Sabbatini, P., White, E. and Prendergast, G.C. (1997) The Polyproline Region of p53 Is Required to Activate Apoptosis But Not Growth Arrest. Oncogene, 15, 887-898. https://doi.org/10.1038/sj.onc.1201263

[23] Song, F., Zheng, H., Liu, B., Wei, S., Dai, H., Zhang, L., Calin, G.A., Hao, X., Wei, Q., Zhang, W. and Chen, K. (2009) An miR-502-Binding Site Single-Nucleotide Polymorphism in the 3'-Untranslated Region of the SET8 Gene Is Associated with Early Age of Breast Cancer Onset. Clinical Cancer Research, 15, 6292-6300. https://doi.org/10.1158/1078-0432.CCR-09-0826

[24] Yang, S., Guo, H., Wei, B., Zhu, S., Cai, Y., Jiang, P. and Tang, J. (2014) Association of miR-502-Binding Site Single Nucleotide Polymorphism in the 3'-Untranslated Region of SET8 and TP53 Codon 72 Polymorphism with Non-Small Cell Lung Cancer in Chinese Population. Acta Biochimica et Biophysica Sinica, 46, 149-154. https://doi.org/10.1093/abbs/gmt138

[25] Yang, S.D., Cai, Y.L., Jiang, P., Li, W. and Tang, J.X. (2014) Association of a miR-502-Binding Site Single Nucleotide Polymorphism in the 3'-Untranslated Region of SET8 and the TP53 Codon 72 Polymorphism with Cervical Cancer in the Chinese Population. Asian Pacific Journal of Cancer Prevention, 15, 6505-6510. https://doi.org/10.7314/APJCP.2014.15.16.6505

[26] West, L.E., Roy, S., Lachmi-Weiner, K., Hayashi, R., Shi, X., Appella, E., Kutateladze, T.G. and Gozani, O. (2010) The MBT Repeats of L3MBTL1 Link SET8-Mediated p53 Methylation at Lysine 382 to Target Gene Repression. The Journal of Biological Chemistry, 285, 37725-37732. https://doi.org/10.1074/jbc.M110.139527

[27] Tardat, M., Murr, R., Herceg, Z., Sardet, C. and Julien, E. (2007) PR-Set7-Dependent Lysine Methylation Ensures Genome Replication and Stability through S Phase. The Journal of Cell Biology, 179, 1413-1426. https://doi.org/10.1083/jcb.200706179

[28] Huen, M.S., Sy, S.M., van Deursen, J.M. and Chen, J. (2008) Direct Interaction between SET8 and Proliferating Cell Nuclear Antigen Couples H4-K20 Methylation with DNA Replication. The Journal of Biological Chemistry, 283, 11073-11077. 
https://doi.org/10.1074/jbc.C700242200

[29] Rivlin, N., Brosh, R., Oren, M. and Rotter, V. (2011) Mutations in the p53 Tumor Suppressor Gene: Important Milestones at the Various Steps of Tumorigenesis. Genes and Cancer, 2, 466-474. https://doi.org/10.1177/1947601911408889

[30] Ofon, E., Noyes, H., Ebo'o Eyanga, V., Njiokou, F., Koffi, M., Fogue, P., HertzFowler, C., MacLeod, A., Matovu, E., Simo, G. and TrypanoGEN Research Group, as Members of the H3Africa Consortium (2019) Association between IL1 Gene Polymorphism and Human African Trypanosomiasis in Populations of Sleeping Sickness Foci of Southern Cameroon. PLoS Neglected Tropical Diseases, 13, e0007283. https://doi.org/10.1371/journal.pntd.0007283

[31] Kouega, J.P. (2007) The Language Situation in Cameroon. Current Issues in Language Planning, 8, 3-93. https://doi.org/10.2167/cilp110.0

[32] Kerney, R. (2010) DNA Extraction Protocol. http://public.gettysburg.edu/ rkerney/Protocols/MolecularBiology/DNAExtraction. pdf

[33] Ye, J., Coulouris, G., Zaretskaya, I., Cutcutache, I., Rozen, S. and Madden, T.L. (2012) Primer-BLAST: A Tool to Design Target-Specific Primers for Polymerase Chain Reaction. BMC Bioinformatics, 13, 134. https://doi.org/10.1186/1471-2105-13-134

[34] Menashe, I., Rosenberg, P.S. and Chen, B.E. (2008) PGA: Power Calculator for Case-Control Genetic Association Analyses. BMC Genetics, 9, 36.

https://doi.org/10.1186/1471-2156-9-36

[35] World Health Organization (2018) Global Health Observatory. World Health Organization, Geneva.

[36] Spencer, C.C., Su, Z., Donnelly, P. and Marchini, J. (2009) Designing Genome-Wide Association Studies: Sample Size, Power, Imputation, and the Choice of Genotyping Chip. PLoS Genetics, 5, e1000477. https://doi.org/10.1371/journal.pgen.1000477

[37] Purcell, S., Neale, B., Todd-Brown, K., Thomas, L., Ferreira, M.A., Bender, D., Maller, J., Sklar, P., de Bakker, P.I., Daly, M.J. and Sham, P.C. (2007) PLINK: A Tool Set for Whole-Genome Association and Population-Based Linkage Analyses. American Journal of Human Genetics, 81, 559-575. https://doi.org/10.1086/519795

[38] Pagano, M. and Gauvreau, K. (2000) Principles of Biostatistics. 2nd Edition, Pacific Grove, Duxbury.

[39] Deeks, J.J. and Higgins, J.P.T. (2010) Statistical Algorithms in Review Manager 5. https://training.cochrane.org/handbook/statistical-methods-revman5

[40] Sasieni, P.D. (1997) From Genotypes to Genes: Doubling the Sample Size. Biometrics, 53, 1253-1261. https://doi.org/10.2307/2533494

[41] Wang, C., Guo, Z., Wu, C., Li, Y. and Kang, S. (2012) A Polymorphism at the miR-502 Binding Site in the 3' Untranslated Region of the SET8 Gene Is Associated with the Risk of Epithelial Ovarian Cancer. Cancer Genetics, 205, 373-376. https://doi.org/10.1016/j.cancergen.2012.04.010

[42] Wall, J.D. and Pritchard, J.K. (2003) Haplotype Blocks and Linkage Disequilibrium in the Human Genome. Nature Reviews Genetics, 4, 587-597. https://doi.org/10.1038/nrg1123

[43] 1000 Genomes Project Consortium, Auton, A., Brooks, L.D., Durbin, R.M., Garrison, E.P., Kang, H.M., Korbel, J.O., Marchini, J.L., McCarthy, S., McVean, G.A. and Abecasis, G.R. (2015) A Global Reference for Human Genetic Variation. Nature, 526, 68-74. https://doi.org/10.1038/nature15393 
[44] Wang, S., Qian, F., Zheng, Y., Ogundiran, T., Ojengbede, O., Zheng, W., Blot, W., Nathanson, K.L., Hennis, A., Nemesure, B., Ambs, S., Olopade, O.I. and Huo, D. (2018) Genetic Variants Demonstrating Flip-Flop Phenomenon and Breast Cancer Risk Prediction among Women of African Ancestry. Breast Cancer Research and Treatment, 168, 703-712. https://doi.org/10.1007/s10549-017-4638-1

[45] Chen, F., Chen, G.K., Stram, D.O., Millikan, R.C., Ambrosone, C.B., John, E.M., Bernstein, L., Zheng, W., Palmer, J.R., Hu, J.J., Rebbeck, T.R., Ziegler, R.G., Nyante, S., Bandera, E.V., Ingles, S.A., Press, M.F., Ruiz-Narvaez, E.A., Deming, S.L., Rodriguez-Gil, J.L., Demichele, A., Haiman, C.A., et al. (2013) A Genome-Wide Association Study of Breast Cancer in Women of African Ancestry. Human Genetics, 132, 39-48. https://doi.org/10.1007/s00439-012-1214-y

[46] Narouie, B., Ziaee, S., Basiri, A. and Hashemi, M. (2017) Functional Polymorphism at the miR-502-Binding Site in the 3' Untranslated Region of the SETD8 Gene Increased the Risk of Prostate Cancer in a Sample of Iranian Population. Gene, 626, 354-357. https://doi.org/10.1016/j.gene.2017.05.060

[47] Murphy, M.E., Liu, S., Yao, S., Huo, D., Liu, Q., Dolfi, S.C., Hirshfield, K.M., Hong, C.C., Hu, Q., Olshan, A.F., Ogundiran, T.O., Adebamowo, C., Domchek, S.M., Nathanson, K.L., Nemesure, B., Ambs, S., Blot, W.J., Feng, Y., John, E.M., Bernstein, L., Ambrosone, C.B., et al. (2017) A Functionally Significant SNP in TP53 and Breast Cancer Risk in African-American Women. NPJ Breast Cancer, 3, 5. https://doi.org/10.1038/s41523-017-0007-9

[48] Aceto, G.M., Awadelkarim, K.D., Di Nicola, M., Moscatello, C., Pantalone, M.R., Verginelli, F., Elwali, N.E. and Mariani-Costantini, R. (2019) Germline TP53 Mutation Spectrum in Sudanese Premenopausal Breast Cancer Patients: Correlations with Reproductive Factors. Breast Cancer Research and Treatment, 175, 479-485. https://doi.org/10.1007/s10549-019-05168-1

[49] Malisic, E.J., Jankovic, R.N., Jakovljevic, K.V. and Radulovic, S.S. (2013) Association of TP53 Codon 72 Polymorphism with Susceptibility to Ovarian Carcinomas in Serbian Women. European Journal of Obstetrics, Gynecology, and Reproductive Biology, 166, 90-93. https://doi.org/10.1016/j.ejogrb.2012.10.002

[50] Dastjerdi, M.N., Aboutorabi, R. and Eslami Farsani, B. (2013) Association of TP53 Gene Codon 72 Polymorphism with Endometriosis Risk in Isfahan. Iranian Journal of Reproductive Medicine, 11, 473-478.

[51] Wahlund, S. (1928) Zusammensetzung von Populationen und Korrelationserscheinungen vom Standpunkt der Vererbungslehre aus Betrachtet. Hereditas, 11, 65-106. https://doi.org/10.1111/j.1601-5223.1928.tb02483.x

[52] Sinnock, P. (1975) The Wahlund Effect for the Two Locus Model. The American Naturalist, 109, 565-570. https://doi.org/10.1086/283027

[53] Hartl, D.L. and Clark, A.G. (2007) Principles of Population Genetics. 4th Edition, Sinauer Associates, Sunderland.

[54] Freedman, M.L., Reich, D., Penney, K.L., McDonald, G.J., Mignault, A.A., Patterson, N., Gabriel, S.B., Topol, E.J., Smoller, J.W., Pato, C.N., Pato, M.T., Petryshen, T.L., Kolonel, L.N., Lander, E.S., Sklar, P., Henderson, B., Hirschhorn, J.N. and Altshuler, D. (2004) Assessing the Impact of Population Stratification on Genetic Association Studies. Nature Genetics, 36, 388-393. https://doi.org/10.1038/ng1333

[55] Marchini, J., Cardon, L.R., Phillips, M.S. and Donnelly, P. (2004) The Effects of Human Population Structure on Large Genetic Association Studies. Nature Genetics, 36, 512-517. https://doi.org/10.1038/ng1337

[56] Chikhi, L., Sousa, V.C., Luisi, P., Goossens, B. and Beaumont, M.A. (2010) The 
Confounding Effects of Population Structure, Genetic Diversity and the Sampling Scheme on the Detection and Quantification of Population Size Changes. Genetics, 186, 983-995. https://doi.org/10.1534/genetics.110.118661

[57] Wittke-Thompson, J.K., Pluzhnikov, A. and Cox, N.J. (2005) Rational Inferences about Departures from Hardy-Weinberg Equilibrium. American Journal of Human Genetics, 76, 967-986. https://doi.org/10.1086/430507

[58] Zintzaras, E. and Lau, J. (2008) Synthesis of Genetic Association Studies for Pertinent Gene-Disease Associations Requires Appropriate Methodological and Statistical Approaches. Journal of Clinical Epidemiology, 61, 634-645. https://doi.org/10.1016/j.jclinepi.2007.12.011

[59] Sillanpää, M.J. (2011) Overview of Techniques to Account for Confounding Due to Population Stratification and Cryptic Relatedness in Genomic Data Association Analyses. Heredity, 106, 511-519. https://doi.org/10.1038/hdy.2010.91

[60] Chen, B., Cole, J.W. and Grond-Ginsbach, C. (2017) Departure from Hardy Weinberg Equilibrium and Genotyping Error. Frontiers in Genetics, 8, 167.

https://doi.org/10.3389/fgene.2017.00167

[61] Cherdyntseva, N.V., Denisov, E.V., Litviakov, N.V., Maksimov, V.N., Malinovskaya, E.A., Babyshkina, N.N., Slonimskaya, E.M., Voevoda, M.I. and Choinzonov, E.L. (2012) Crosstalk between the FGFR2 and TP53 Genes in Breast Cancer: Data from an Association Study and Epistatic Interaction Analysis. DNA and Cell Biology, 31, 306-316. https://doi.org/10.1089/dna.2011.1351

[62] Murphy, M.E. (2006) Polymorphic Variants in the p53 Pathway. Cell Death and Differentiation, 13, 916-920. https://doi.org/10.1038/sj.cdd.4401907

[63] Chen, R., Liu, S., Ye, H., Li, J., Du, Y., Chen, L., Liu, X., Ding, Y., Li, Q., Mao, Y., Ai, S., Zhang, P., Ma, W. and Yang, H. (2015) Association of p53 rs1042522, MDM2 rs2279744, and p21 rs1801270 Polymorphisms with Retinoblastoma Risk and Invasion in a Chinese Population. Scientific Reports, 5, Article No. 13300. https://doi.org/10.1038/srep13300

[64] Brenna, S.M.F., Silva, D.C.G., Zeferino, L.C., Pereira, J., Martinez, E.Z. and Syrjänen, K.J. (2004) Prevalence of Codon 72 P53 Polymorphism in Brazilian Women with Cervix Cancer. Genetics and Molecular Biology, 27, 496-499. https://doi.org/10.1590/S1415-47572004000400005

[65] Leu, J.D., Wang, C.Y., Tsai, H.Y., Lin, I.F., Chen, R.C. and Lee, Y.J. (2011) Involvement of p53 R72P Polymorphism in the Association of MDM2-SNP309 with Breast Cancer. Oncology Reports, 25, 1755-1763.

[66] Beckman, G., Birgander, R., Själander, A., Saha, N., Holmberg, P.A., Kivelä, A. and Beckman, L. (1994) Is p53 Polymorphism Maintained by Natural Selection? Human Heredity, 44, 266-270. https://doi.org/10.1159/000154228

[67] Shi, X., Kachirskaia, I., Yamaguchi, H., West, L.E., Wen, H., Wang, E.W., Dutta, S., Appella, E. and Gozani, O. (2007) Modulation of p53 Function by SET8-Mediated Methylation at Lysine 382. Molecular Cell, 27, 636-646.

https://doi.org/10.1016/j.molcel.2007.07.012

[68] Doosti, A., Dehkordi, G.P. and Davoudi, N. (2011) A p53 Codon 72 Polymorphism Associated with Breast Cancer in Iranian Patients, African Journal of Pharmacy and Pharmacology, 5, 1278-1281. https://doi.org/10.5897/AJPP10.394 